\title{
Application of enzyme multibiosensor for toxicity analysis of real water samples of different origin.
}

\author{
O.O. Soldatkin ${ }^{1}$, O.S. Pavluchenko ${ }^{2}$, O.L. Kukla ${ }^{2}$, I.S. Kucherenko ${ }^{1,3}$, \\ V.M. Peshkova', ${ }^{1,}$ V.M. Arkhypova ${ }^{1}$, S.V. Dzyadevych ${ }^{1}$, A.P. Soldatkin ${ }^{1}$, \\ A.V. El'skaya ${ }^{1}$
}

\footnotetext{
${ }^{1}$ Institute of molecular biology and genetics NAS of Ukraine 150, Zabolotnogo Str, Kyiv Ukraine, 03680

${ }^{2}$ V.Lashkaryov Institute of Semiconductor Physics

41, prospect Nauki, Kyiv, Ukraine, 03028

${ }^{3}$ National Taras Shevchenko University of Kyiv

64, Volodymyrska Str, Kyiv, Ukraine 01033
}

alex_sold@yahoo.com,kukla@isp.kiev.ua

\begin{abstract}
Aim. The analysis of toxicity of different water samples with the multibiosensor developed earlier. Methods. The potentiometric multibiosensor with several immobilized enzymes as bioselective elements and the matrix of pH-sensitive field effect transistors as transducers of the biochemical signal into the electric one was applied for the analysis. Results. The bioselective elements of the multibiosensor were developed using acetylcholinesterase, butyryl-cholinesterase, urease, glucose oxidase, and three-enzyme system (invertase, mutarotase, glucose oxidase). The measurement of toxic compounds in water samples of different origin was performed using the constructed sensor. The results obtained were compared with those obtained by the conventional methods of toxic agent's analysis (atomic absorption spectrometry, thin-film chromatography, and atomic absorbic analyser of mercury). Conclusion. A strong conformity between the results obtained with the multibiosensor and traditional methods has been shown.
\end{abstract}

Keywords: multibiosensor, pH-sensitive field-effect transistors, enzymes, inhibitory analysis, pesticide, ions of heavy metal, toxins.

Introduction. A remarkable interest paid to biosensors during two last decades is determined by their advantages comparing with traditional physical-chemical and biochemical methods of

(C) Institute of Molecular Biology and Genetics NAS of Ukraine, 2009 analysis: relatively low cost and simple application along with high sensitivity, specificity and possibility to analyze colored samples $[1,2]$. Biosensors can be used in the fields of medical diagnostics, environmental protection and agriculture [3]. Today an 


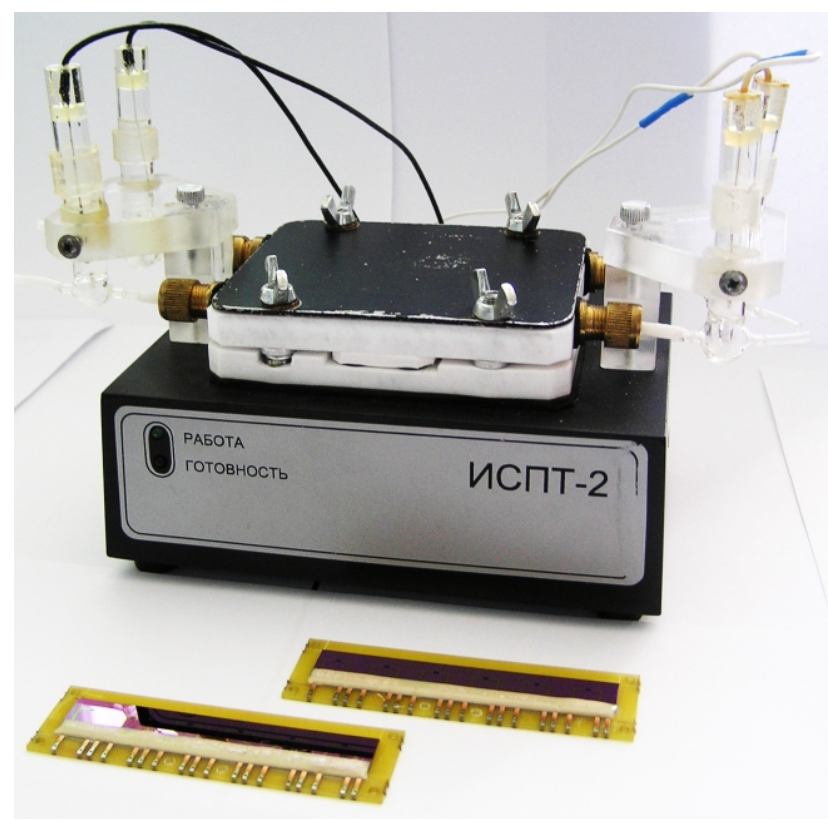

Fig. 1. General view of multisensor device

advanced challenge is the development of biosensor systems for toxins determination.

At present, there are a number of commercial enzyme biosensor devices for analysis of glucose, ethanol, urea, etc. [4], however, none is known to be applied for the determination of heavy metal ions and pesticides. The authors have developed a laboratory prototype of multibiosensor for express identification of toxins in aqueous solutions $[5,6]$. The characteristics obtained are promising in respect to usage of this model as a basis for designing a commercial version of measuring device for both integral and, to some extent, selective determination of toxic substances.

Comparing to known standard methods, the multibiosensor system suggested is essentially advantageous $[7,8]$ because of:

a possibility of measurements of toxins in water samples without their pretreatment;

short duration of analysis, the procedure does not exceed 40 minutes;

small quantity of reagent consumption and low price of working elements at industrial production;

a simple measuring procedure and, thus, no particular requirements toward personnel qualification.

The goal of the investigation presented was to compare the results of determination of toxin concentration in real water samples from different sources, obtained with the developed multibiosensor and traditional analytical methods.

Materials and Methods. The following frozen-dried preparations of enzymes were used: soybean urease (activity index of $31 \mathrm{U} / \mathrm{mg}$ ) (Fluka, Switzerland); acetylcholinesterase (AChE) (activity index of 292 units $/ \mathrm{mg}$ ) from Electric Eel (Sigma-Aldrich Chemie, USA); butyrylcholinesterase (BuChE) (activity index $13 \mathrm{U} / \mathrm{mg}$ ) from horse blood serum (Sigma-Aldrich Chemie), glucose oxidase (GOD) from Penicilium vitale (activity index 130 U/mg) (Diagnosticum, Lviv, Ukraine); baker's yeast invertase (activity index of $355 \mathrm{U} / \mathrm{mg}$ ) (Sigma-Aldrich Chemie), pig kidney mutarotase (activity index of $100 \mathrm{U} / \mathrm{mg}$ ) (Biozyme Laboratories Ltd, UK). Bovine serum albumin (BSA) (fraction V) and $50 \%$ aqueous solution of glutaraldehyde (GA) were purchased from Sigma-Aldrich Chemie. The following substrates were used: urea, butyrylcholine chloride $\mathrm{BuChCl}$, acetylcholine chloride $\mathrm{AChCl}$, glucose, and succhrose. Phosphate solution $\left(\mathrm{KH}_{2} \mathrm{PO}_{4}-\mathrm{NaOH}\right)$ was chosen as a working buffer. Other inorganic compounds used were of domestic production and of analytical grade.

Multisensor device. General view of the multisensor device with 12-channel integral sensor array on the basis of ion-selective ( $\mathrm{pH}$-sensitive) filed-effect transistors (ISFET) is shown in Fig.1.

The device functions due to the formation of multisignal response of the array of electrochemical sensors based on ISFETs with $\mathrm{pH}$-sensitive layer of silicon nitride. The change in surface potential at electrolyte-transducer gate interface is measured by each sensor element of the array. The data obtained are processed using methods of discriminate analysis, which results in generation of the unique chemical pattern of the liquid sample tested.

Measurement procedure. The measurement was carried out at room temperature in $2 \mathrm{mM}$ phosphate buffer, $\mathrm{pH}$ 6.5, using flow system. The substrates concentration in a cell was varied by addition of portions of the stock solutions of standard concentration into the working buffer. The bioselective elements were incubated for $20 \mathrm{~min}$ in solutions of water samples of different origin. The results of 


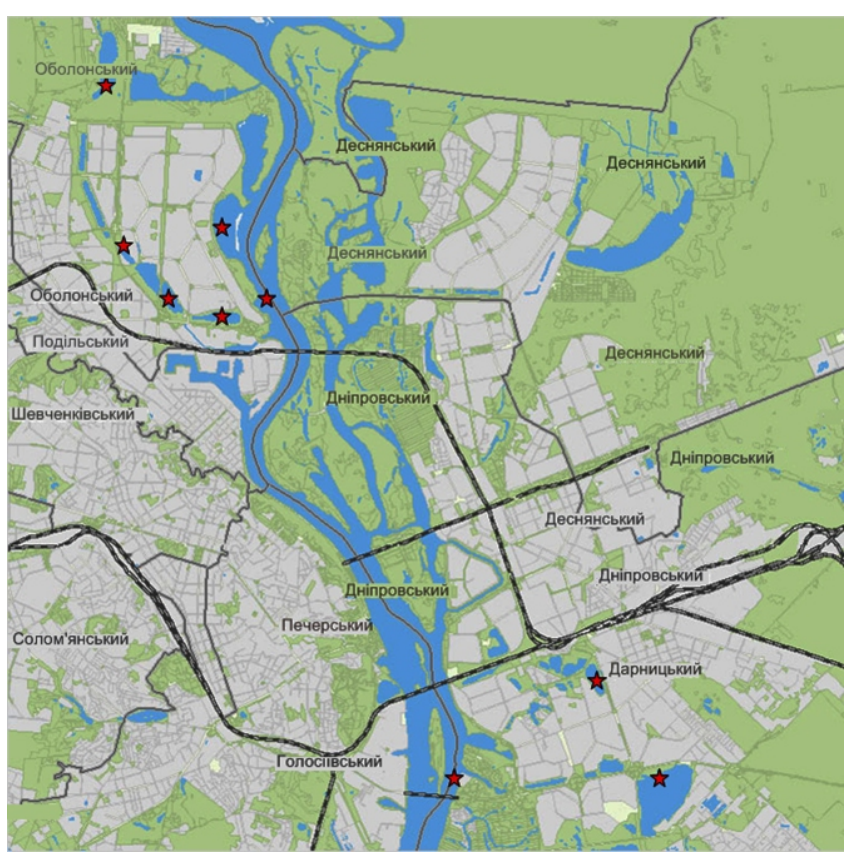

Fig. 2. Fragment of Kiev map (the places where the samples were taken are indicated with asterisks)

samples toxicity obtained by the multibiosensor were compared with those got by traditional analytical methods, i.e. atomic absorption spectrometry, thin-layer chromatography and absorption mercury analyzer. Each measurement was performed at least three times. Nonspecific changes in the output signal caused by temperature and medium $\mathrm{pH}$ oscillations, as well as by electric noise, were eliminated due to differential mode of measurement.

Results and discussion. To examine operational capability of the multibiosensor developed, natural water samples were tested as to the presence of toxins. The water samples were taken from several Kiev water pools, especially in the most popular places of people recreation, i.e. municipal beaches of Obolon and Darnitsa districts (see a fragment of Kiev map - Fig. 2). They are: the lakes Vyrlytsa, Sonyachne, Ministerske, Opechen, Lower Opechen, as well as the Dnipro River in the vicinity of Moscow and Pivdenny (South) bridges and Obolon bay.

A potential of the multibiosensor for analysis of polycomponent complex samples was evaluated, for which along with above mentioned samples, the aqueuos assays from the landfill of solid domestic waste in Pidgirtsi village (Kyiv region) were analyzed.

Analyzing the selected samples with the multibiosensor we have revealed that none of the bioselective elements are inhibited by the water samples from the Kiev pools (Table 1).

To prove an adequacy of multibiosensor operating, some toxins of known concentrations were added to the samples tested. As seen from Table 1, a distinct signal of corresponding bioselective elements was revealed due to the inhibition by certain toxins. It testifies to the absence of pesticides and heavy metal ions in the water pools in Kiev region.

A more complicated situation arises at inhibitory analysis of the sample taken from Kiev landfill No. 5 of solid domestic waste. After the multibiosensor incubation in the assays tested, the sensitive elements completely lost their ability to respond to the substrate addition. The reason for this could be either $100 \%$ inhibition of all enzymes used or/and the blocking of pores of bioselective membranes with colloidal particles present in the sample, which decreases their permeability.

To avoid mechanical barrier, the assay was filtered and centrifuged for removal of large-scale particles. The best result was obtained by means of filtrating through «Sartorius» filter with $20 \mu \mathrm{m}$ pores (Table 2 ). Thus, assay pretreatment is necessary to remove large-scale particles decreasing permeability of the bioselective membranes. After their eliminating the residual inhibitory activity of such sample may be considered definitely as a result of the toxins presence. According to the results of inhibition of the bioselective membranes based on urease, GOD and three-enzyme system, these toxins are heavy metal ions [6].

Control analysis of toxins content in water samples by traditional methods. All samples tested with the multibiosensor were controlled in L.I. Medved' Institute of ecohygiene and toxicology (Kiev, Ukraine) using traditional analytical methods (Table 3).

Pesticides were measured in the samples, taken from Kiev No. 5 landfill of domestic waste and from Kiev water pools, by thin-layer chromatography in 
Bioselective elements inhibition with water samples originating from different areas (100\% - complete inhibition)

\begin{tabular}{|c|c|c|c|c|c|}
\hline \multirow{2}{*}{ Screened area } & \multicolumn{5}{|c|}{ Level of inhibition (\%) of bioselective elements } \\
\hline & Urease & BuChE & $\mathrm{AChE}$ & GOD & $\begin{array}{c}\text { Three-enzyme } \\
\text { system }\end{array}$ \\
\hline Vyrlytsa lake (Poznyaky) & 0 & 0 & 0 & 0 & 0 \\
\hline Vyrlytsa lake (Poznyaky) (400 nM Hg ${ }^{2+}$ added $)$ & 0 & 0 & 0 & 5 & 10 \\
\hline Dnieper river (Osokorky) & 0 & 0 & 0 & 0 & 0 \\
\hline $\begin{array}{c}\text { Dnieper river (Osokorky) }(10 \mu \mathrm{M} \text { trichlorfon } \\
\text { added) }\end{array}$ & 0 & 50 & 5 & 0 & 0 \\
\hline Sonyachne lake (Osokorky) & 0 & 0 & 0 & 0 & 0 \\
\hline Sonyachne lake (Osokorky) (5 $\boldsymbol{\mu} \mathbf{M ~} \mathbf{C u}^{2+}$ added) & 7 & 0 & 0 & 0 & 0 \\
\hline Ministerske lake (Obolon) & 0 & 0 & 0 & 0 & 0 \\
\hline Opechen lake (Obolon) & 0 & 0 & 0 & 0 & 0 \\
\hline Lower Opechen lake (Obolon) & 0 & 0 & 0 & 0 & 0 \\
\hline Verbne lake (Obolon) & 0 & 0 & 0 & 0 & 0 \\
\hline Dnipro River, Obolon bay (Obolon) & 0 & 0 & 0 & 0 & 0 \\
\hline $\begin{array}{l}\text { Dnipro River, vicinity of Moscow bridge } \\
\text { (Obolon) }\end{array}$ & 0 & 0 & 0 & 0 & 0 \\
\hline Kiev landfill No. 5 of domestic waste & 100 & 100 & 100 & 100 & 100 \\
\hline
\end{tabular}

accordance with the manual operation [9]; no pesticides were revealed

Mercury was determined on the atomic absorption mercury analyzer "Julia-2". To measure other heavy metal ions, the samples were placed one by one into a crucible and burnt in a muffle furnace. The residues were dissolved in nitric acid, and heavy metals were determined in the obtained solution by atomic absorption spectroscopy on the apparatus Z-8000 (Hitachi, Japan).

Analysis of the data presented in Table 3 shows their good correlation with the results obtained with the multibiosensor. As could be expected an excess of concentration of toxins over maximum allowable content was revealed in the samples from Kiev water pools to which corresponding toxin aliquots were deliberately added, i.e. for mercury (line 2), copper (line 6) and trichlorfon (line 4). No toxins in hazardous concentration were revealed by traditional methods (as well as with the multibiosensor) in the rest of the samples. As to the samples from Kiev landfill No. 5 of domestic waste, by traditional methods an excess of the maximum allowable content was registered for copper, zinc and chromium, while mercury and pesticides were not revealed at all (line 13) which is in good agreement with the data obtained with the biosensor.

Thus, the results of analysis of all water samples obtained by traditional methods confirm the data of multibiosensor measurement.

Conclusion. A number of experiments concerning determination of toxicity of assays taken from Kiev water pools and from Kiev landfill No. 5 of domestic waste were performed. The content of toxic substances in the assays was analyzed by traditional methods and with the developed multibiosensor; the 
Table 2

Inhibition of bioselective elements of multobiosensor with samples taken from Kiev landfill No. 5 of solid domestic waste after different procedures of sample pretreatment (100\% - complete inhibition)

\begin{tabular}{|c|c|c|c|c|c|}
\hline \multirow{2}{*}{ Procedure of sample pretreatment } & \multicolumn{5}{|c|}{ Level of inhibition (\%) of bioselective elements } \\
\hline & Urease & $\mathrm{BuChE}$ & $\mathrm{AChE}$ & GOD & $\begin{array}{l}\text { Three-enzyme } \\
\text { system }\end{array}$ \\
\hline Without pretreatment & 100 & 100 & 100 & 100 & 100 \\
\hline Centrifugation & 75 & 45 & 50 & 70 & 75 \\
\hline Filtration through filter paper & 60 & 20 & 30 & 55 & 60 \\
\hline Filtration through standard filter "Sartorius", $\mathrm{d}=45 \mu \mathrm{m}$ & 45 & 5 & 8 & 30 & 40 \\
\hline Filtration through standard filter "Sartorius", $\mathrm{d}=20 \mu \mathrm{m}$ & 40 & 3 & 8 & 20 & 30 \\
\hline
\end{tabular}

Table 3

Toxins concentration in water samples measured by traditional methods

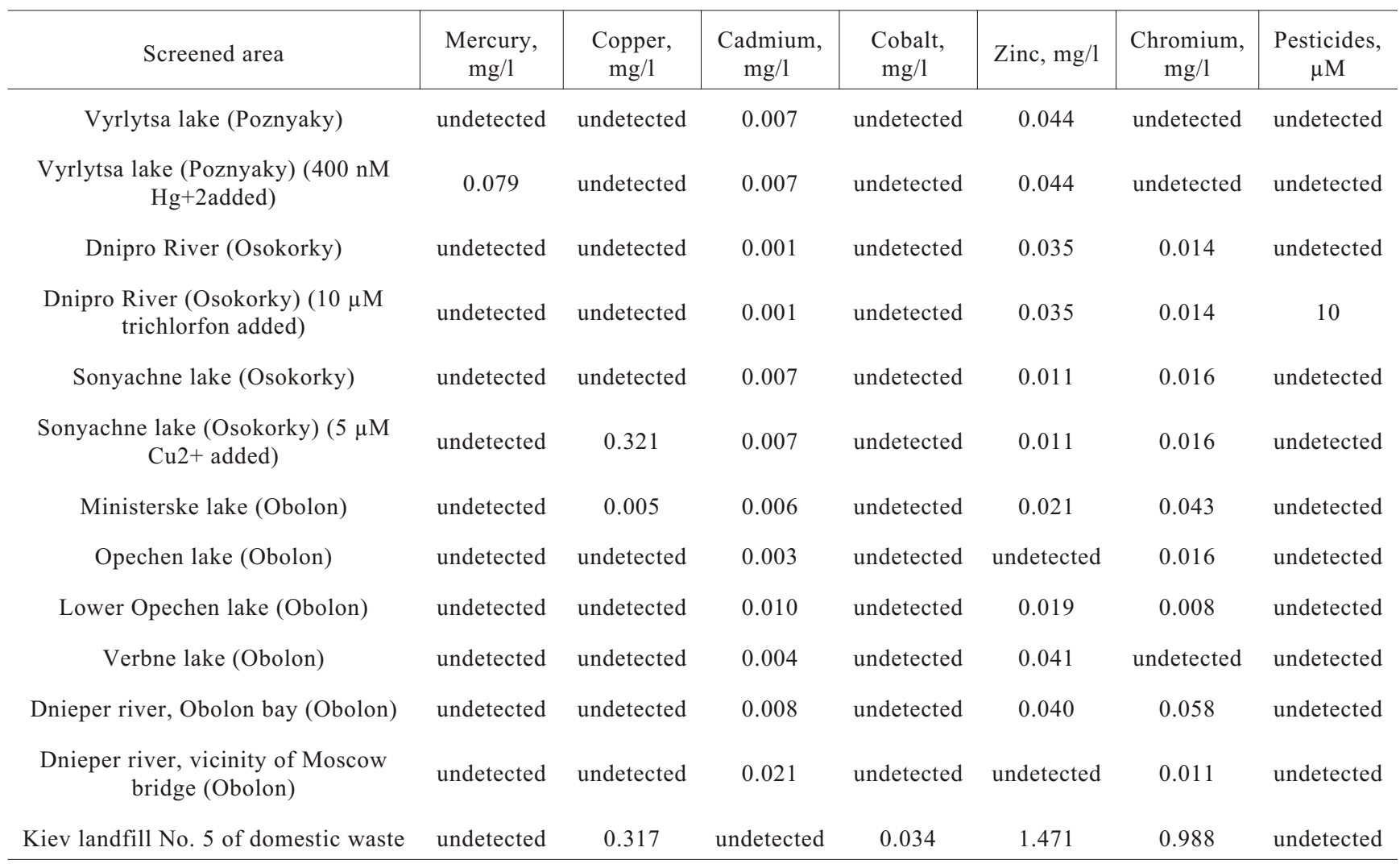

data obtained were compared; a good correlation of the results was shown. Therefore, the developed multibiosensor system was experimentally proved to be potentially applicable as an express analyzer of toxicity of water assays. It is valid for fast determination of sample toxicity under field conditions, identification of toxins or toxin groups, and proposition of using the optimal traditional method for further, precise determination of the toxins revealed. 
О. О. Солдаткін, О. С. Павлюченко, О. Л. Кукла,

I. С. Кучеренко, В. М. Пєшкова, В. М. Архипова, С. В. Дзядевич, О. П. Солдаткін, Г. В. Сльська

Використання ферментного мультибіосенсора при аналізі токсичності реальних водних зразків різного походження

Резюме

Мета. 3 використанням розробленого мультибіосенсора зробити аналіз токсичності реальних водних зразків. Методи. Застосовано потенціометричний мультибіосенсор з низкою іммобілізованих ферментів та матрииі іоноселективних польових транзисторів як перетворювачів біохімічного сигналу в електричний. Результати. Біоселективні елементи у складі мультибіосенсора створено на основі ацетилхолінестерази, бутирилхолінестерази, уреази, глюкозооксидази та триферментної системи (інвертаза, мутаротаза, глюкозооксидаза). За допомогою розробленого аналізатора виконано експерименти з визначення токсичних речовин у водних зразках різного походження. Отримані дані порівняно з результатами, одержаними стандартними традиційними методами аналізу токсичних речовин (атомна абсорбиійна спектроскопія, тонкошарова хроматографія та атомно-абсорбчійний аналізатор ртуті). Висновки. Показано кореляиію результатів, одержаних мультибіосенсорним і традиційними методами.

Ключові слова: Мультибіосенсор, іоноселективні польові транзистори, ферменти, інгібіторний аналіз, пестициди, іони важких металів, токсичні речовини.

А. А. Солдаткин, О. С. Павлюченко, О. Л. Кукла,

И. С. Кучеренко, В. М. Пешкова, В. М. Архипова, С. В. Дзядевич, А. П. Солдаткин, А. В. Ельская

Использование ферментного мультибиосенсора при анализе токсичности реальных водных образцов разного

происхождения

Резюме

Цель. С использованием разработанного мультибиосенсора провести анализ токсичности реальных водных образиов. Методы. Применен потенциометрический мультибиосенсор с рядом иммобилизованных ферментов и матрииы ионоселективных полевых транзисторов как преобразователей биохимического сигнала в электрический. Результаты. Биоселективные элементы в составе мультибиосенсора созданы на основе ацетилхолинэстеразы, бутирилхолинэстеразы, уреазы, глюкозооксидазы и трехферментной системы (инвертаза, мутаротаза, глюкозооксидаза). С помощью разработанного анализатора выполнен ряд экспериментов по определению токсичных веществ в водных образиах разного происхождения. Собственные данные сравнивали с результатами, полученными стандартными традиционными методами анализа токсичных веществ (атомная абсорбиионная спектроскопия, тонкослойная хроматография и атомно-абсорбциионный анализатор ртути). Выводы. Показана корреляция результатов, полученных мультибиосенсорным $и$ традиционными методами.

Ключевые слова: мультибиосенсор, ионоселективные полевые транзисторы, ферменты, ингибиторный анализ, пестициды, ионы тяжельх металлов, токсические вещества.

\section{REFERENCES}

1. Coulet P. R. What is a biosensor// Biosensor principles and application / Eds L. J. Blum, P. R. Coulet.-New York: Marcel Dekker, 1991.-P. 1-6.

2. Thevenot D. R., Toth K., Durst R. A., Wilson G. S. Electrochemical biosensors: recommended definitions and classification (Technical report) // Pure Appl. Chem.-1999.-71.P. 2333-2348.

3. Hall E. A. H. Recent progress in biosensor development// Int. J. Biochem.-1988.-20, № 4.-P. 357-362.

4. Scheller F. W., Pfeiffer D. Commercial Devices based on amperometric biosensors // Handbook of biosensors and electronic noses: medicine, food, and environment / Ed. E. Kress-Rogers.-New York: CRC press, 1997.-P. 245-256.

5. Soldatkin O. O., Pavluchenko O. S., Kukla O. L., Arkhipova V. M., Dzyadevych S. V., Soldatkin O. P., El'skaya A. V. Optimization of enzymatic bioselective elements as components of potentiometric multibiosensor // Biopolymers and Cell.-2008.-24, N 1.-P. 42-50.

6. Soldatkin O. O., Pavluchenko O. S., Kukla O. L., Arkhipova V. M., Dzyadevych S. V., Soldatkin O. P., El'skaya A. V. Optimization of multibiosensor operation for inhibitory analysis of toxins // Biopolymers and Cell.-2008.-24, N 6.-P. 494502.

7. Sherma J., Zweig G. Pesticides // Anal. Chem.-1983.-55.P. 57.

8. Tran-Minh C., Pandey P. C., Kumaran S. Studies on acetylcholine sensor and its analytical application based on the inhibition of cholinesterase // Biosensors and Bioelectronics.-1990.-5.-P. 461-471.

9. Metodicheskie ukazaniya po opredeleniyu pestizidov v vode, produktach, kormach i tabachnych izdeliyach metodom chromotografii v tonkom sloe № 2142-80 ot 28.01.1980 g.

UDC 577.151.4:544.475:543.554.2 Received 10.10.08 